\title{
Heterologous Liver Perfusion in Acute Hepatic Failure
}

\author{
J. McK. WATTS,* M.B., F.R.A.C.S. ; M. C. DOUGLAS, † M.B., B.S. \\ H. A. F. DUDLEY, $\ddagger$ CH.M., F.R.C.S.ED., F.R.A.C.S. ; F. W. GURR, $\S$ M.D., M.R.A.C.P. \\ J. A. OWEN,\| M.D., PH.D., M.C.P.A., M.C.PATH.
}

Brit. med. F., 1967, 2, 341-345

When a patient with liver disease becomes comatose the outlook is grave whatever the underlying pathological process (Foulk et al., 1955 ; Katz et al., 1962 ; McDonald and de la Harpe, 1963 ; Cook and Sherlock, 1965). The usual regimen of management for such a patient (Sherlock, 1963) is designed to maintain life until recovery of hepatic function occurs and to minimize ammonia intoxication.

Recently further specific methods of treatment have been employed-cross-circulation (Burnell et al., 1965), exchange transfusion (Lee and Tink, 1958 ; Trey et al., 1966 ; Berger et al., 1966) homologous liver perfusion (Sen et al., 1966), heterologous liver perfusion (Eiseman et al., 1965 ; Eiseman, 1966), and temporary homologous or heterologous liver transplantation (Starzl et al., 1966).

(Continued from p. 340)

\section{REFERENCES}

Barnes, D. W. H., and Loutit, L. F. (1956). In Progress in Radiobiology, edited by J. S. Mitchell, B. E. Holmes, and C. L. Smith, p. 291. Edinburgh.

Bensted, J. P. M. (1960). Personal communication.

Berkman, J., Netsky, M. G., and Zimmerman, H. M. (1951). F. Neuropath. exp. Neurol., 10, 100.

Bhagwati, S. N., and McKissock, W. (1961). Brit. F. Surg., 48, 672.

Billingham, R. E. (1958). Ann. N.Y. Acad. Sci., 73, 782.

Bouroncle, B. A. (1966). Blood, 27, 544.

Brain, Lord (1963). Lancet, 1, 179 .'

Brain, Lord (1963). Lancet, 198. 1 Ibid., 2, 971.

Burgoon, C. F., jun., Burgoon, J. S., and Baldridge, G. D. (1957). 7. Amer. med. Ass., 164, 265.

Cauchi, M. N., and Field, E. O. (1967). In press.

Cook, P. L., Jelliffe, A. M., Kendall, B., and McLoughlin, M. J. (1966). Brit. F. Radiol., 39, 561 .

Dameshek, W. (1965). Quoted by W. Dameshek, Lancet, 1966, 1, 1268. and Schwartz, R. S. (1959). Blood, 14, 1151.

Davidsohn, I., and Lee, C. L. (1962). Med. Clin. N. Amer., 46, 225.

Davis, W. E., jun., Cole, L. J., Foley, W. A., and Rosen, V. J. (1963). Radiat. Res., 20, 43.

Dayan, A. D., Morgan, H. G., Hope-Stone, H. F., and Boucher, B. J. (1964). Amer. . Roentgenol., 92, 116.

Dowsett, E. G. (1966). Brit. F. Cancer, 20,16

Field, B. O., and Gibbs, J. E. (1966). Clin. exp. Immunol., 1, 195.

Ford, C. E., Hamerton, J. L. L. Barnes, D. W. H., and Loutit, J. F. (1956). Nature (Lond.), 177, 452.

Gilmore, H. K., uun., ana Zelesnick, G. (1962). Penn. med. F., 65, 1047.

Goia, I. (1935). Sang, 9, 367.

Gowans, J. L., and Knight, E. J. (1964). Proc. roy. Soc. B, 159, 257.

Green, I., and Corso, P. F. (1959). Blood, 14, 235.

Hodgkin, T. (1832). Med.-chir. Trans., 17, 68.
Hoffbrand, B. I. (1965). Brit. med. Ұ., 1, 1592.

Jackson, H., jun., and Parker, F., jun. (1947). Hodgkin's Disease and Allied Disorders, p. 3 (classification), p. 14 (familial Hodgkin's).

New York. 1948$)$ f. nat. Cancer Inst., 8, 191.

(1949). Ibid., 10, 267.

- (1950). Ibid., 11, 83.

- (1962). Radiology, 78, 553.

- and Brown, M. B. (1954). Science, 119, 439.

- and Rosston, B. H. (1959a). Transplant. Bull., 6, 107

- (1959b). Stanf. med. Bull., 17, 77.

and Smithers, D. W. (1959). Lancet, 2, 1 .

Kaufman, G. (1965). Arch. Neurol. (Chic.), 13, 555.

Kelly, W. D., Good, R. A., and Varco, R. L. (1958). Surg. Gynec.

Kenis, Y., D Dustin, P., jun., and Peltzer, T. (1958). Acta haemat. (Basel), 20, 329.

Kuper, S. W. A., and Bignall, J. R. (1964). Lancet, 1, 1412.

Law, L. W., and Potter, M. (1958). \%. nat. Cancer Inst., $20,489$.

Litvak, J., L̇eder, M. M., and Kauvar, A. J. (1964). F. Neurosurg., 21,

Ljungdahl, I., Strang, R. R., and Tovi, D. (1965). Neurochirurgia (Stuttg.), $8,113$.

Loehry, C. A. (1964). Brit. med. F., 2, 1594.
In the past six months five patients in coma have been referred to us for consideration of heterologous liver perfusion. Three of them have undergone perfusion and one of the three has survived. The remaining two patients, both with coma supervening on chronic liver disease, recovered consciousness after correction of precipitating factors and did not require perfusion. We describe here the course of the three patients with acute hepatic failure treated by heterologous liver perfusion.

\footnotetext{
* Senior Lecturer, Department of Surgery, Monash University.

† Research Associate, Department of Surgery, Monash University. Currently Lecturer in Surgery, Monash University.

¥ Chairman, Department of Surgery, Monash University.

$\S$ Director, Dialysis Unit, Alfred Hospital, Melbourne.

|| Director, Department of Biochemistry, Alfred Hospital, Melbourne.
}

Lukes, R. J., Butler, J. J., and Hicks, E. B. (1966). Cancer (Philad.), 19

Lundin, F. E., jun., Fraumeni, J. F., jun., Lloyd, W., and Smith, E. M. (1966). F. nat. Cancer Inst., 37, 123.

Marchesi, V. T., and Gowans, J. L. (1964). Proc. roy. Soc. B, 159, 283. Marshall, A. H. E., and Wood, C. (1957). 7. Path. Bact., 73, 163.

Massey, F. C., Lane, L. L., and Imbriglia, J. E. (1953).' F. Amer. med. Ass., 151, 994.

Miles, C. P., Geller, W., and O'Neill, F. (1966). Cancer (Philad.), 19, 1103.

Miller, D. (1965). In Immunological Diseases, edited by M. Samter and H. L. Alexander, p. 372. Boston.

Miller, J. F. A. P. (1961). Lancet, 2, 748.

(1962). Proc. roy. Soc. B, 156, 415.

Peters, M. V., and Middlemiss, K. C. H. (1958). Amer. F. Roentgenol., $79,114$.

Rask-Nielsen, R. (1964). Proc. Soc. exp. Biol. (N.Y.), 116, 1154

Razis, D. V., Diamond, H. D., and Craver, L. F. (1959). Ann. intern.

Med., 51, 933 .

Ricci, N., Punturieri, E., Bosi, L., and Castoldi, G. L. (1962). Lancet, 2 564.

Richards, P., and McKissock, W. (1963). Brit. med. f., 1, 15.

Rigby, P. G., Rosenlof, R. C., Pratt, P. T., and Lemon, H. M. (1966) 7. Amer. med. Ass., 197, 25.

Rosenberg, R. A., and Kaplan, H. S. (1966). Cancer Res., 26, 1225.

Scheer, A. C. (1963). Amer. F. Roentgenol., 90, 939.

Schier, W. W. (1954). Blood, 9, 236.

Schricker, J. L., jun., and Smith, D. E. (1955). Cancer (Philad.), 8, 629.

Schwartz, R. S., and Beldotti, L. (1965). Science, 149, 1511

Schwarz, G., Lee, B. J., and Nelson, J. H. (1965). Acta radiol. Diagn. 3, 138 .

Simonsen, M. (1957). Acta path. microbiol. scand., 40, 480.

Sinkovics, J. G. (1962a). F. infect. Dis., 110, 282

(1962b). Arch. ges. Virusforsch., 12, 143

Smith, C. A. (1934). F. Pediat., 4, 12

Smithers, D. W. (1956). Proc., roy. Soc. Med., 49, 103.

(1959). 7. Fac. Radiol. (Lond.), 10, 3.

Sparling, H. J., jun., and Adams, R.'D. (1946). Arch. Path., 42, 338.

- and Parker, F., jun. (1947). Medicine (Baltimore), 26, 285

Spriggs, A. I., and Boddington, M. M. (1962). Lancet, 2, 153.

Stanley, N. F. (1966). Ibid., 1, 961. I. I. (1966). Ibid., 1, 962.

and Walters, M. N.-I. (1966). Ibid., 1, 962. (N.Y.), 121, 90.

Storniello, G., and Salvati, F: (1963). Riv. Anat. pat., 24, 457

Symmers, D. (1944). Arch. intern. Med., 74, 163.

Thomson, A. D. (1955). Brit. 7. Cancer, 9, 37.

(1956). Proc. roy. Soc. Med., 49, 97.

Trentin, J. J. (1957). Transplant. Bull., 4, 74

Uddströmer, M. (1934). Acta tuberc. pneumol. scand., Suppl. No. 1, $\mathrm{pp}_{.}$49, 178.

20,83 .

Wilkinson, P. C. (1964). Lancet, 1, 1301.

Williams, H. M. Diamond, H. D., Craver, L. F, and Parsons, H. (1959) Neurological Complications of Lymphomas and Leukemias, p. 134 Springfield, Illinois.

Winkelman, N. W., and Moore, M. T. (1941). Arch. Neurol. Psychiat., 45, 304 . 


\section{Technique of Extracorporeal, Heterologous Liver Perfusion}

The technique used closely followed that reported by Eiseman et al. (1966). The liver (1,000 to $1,200 \mathrm{~g}$.) was removed from a $30-40-\mathrm{kg}$. pig under aseptic conditions. The cystic duct was ligated and the common bile duct, hepatic artery, portal vein, and inferior vena cava were cannulated before flushing the hepatic vascular tree free from blood with heparinized Ringer's lactate. The liver was then transferred into an extracorporeal circuit, illustrated diagrammatically in Fig. 1. From an indwelling arteriovenous shunt (Nayman, 1964) arterial blood from the patient was introduced, via a heat exchanger, into the hepatic artery and portal vein of the pig liver. Venous blood drained by gravity into the venous reservoir and from there was pumped back to the patient. Whole-body heparinization was used in three perfusions and regional heparinization of the circuit in three. Fluid exuding from the liver surface was collected and its volume replaced by a continuous infusion of $5 \%$ human serum albumin. Liver temperature and blood $\mathrm{pH}$ were kept within physiological ranges; flow rate and blood chemistry (including arterial $\mathrm{PO}_{2}$ and $\mathrm{PCO}_{2}$ ) were measured intermittently. Bile was collected at 30-minute intervals.

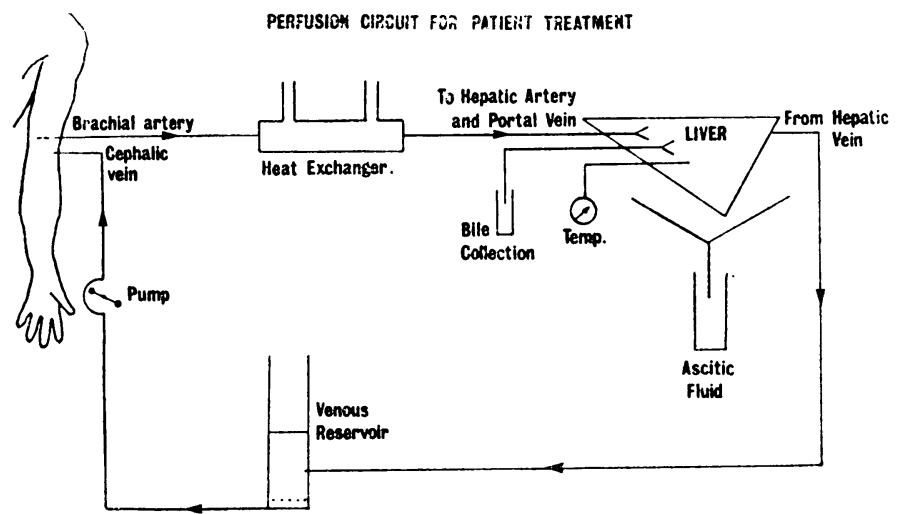

FIG. 1.-Diagram of the extracorporeal circuit used in the six perfusions.

\section{Case 1}

A 41-year-old housewife was admitted to hospital in April 1966 with a history of increasing tiredness and jaundice for four weeks. Seven months previously a malignant melanoma of the forehead had been excised. There was no history of previous liver disease, excessive alcoholic intake, or recent exposure to infectious hepatitis. For six months she had suffered recurrent bouts of fever, treated with short courses of penicillin, tetracycline, and possibly erythromycin. Increasing weakness and loss of weight occurred over this period, but no diagnosis was established.

On referral she was anxious, disorientated, and deeply jaundiced. Her blood pressure was $110 / 80 \mathrm{~mm}$. $\mathrm{Hg}$, pulse $110 / \mathrm{min}$, and temperature $37.6^{\circ} \mathrm{C}$. Cardiovascular and respiratory systems were normal. There was a coarse tremor of both hands but no fetor. The liver edge extended $2 \mathrm{~cm}$. below the costal margin and the spleen was palpable. Moderate ascites and peripheral oedema were present. Lumbar puncture and chest $x$-ray examination showed nothing abnormal.
For two days she was febrile and lethargic with increasing oedema and hyponatraemia. On the third day she developed marked asterixis and became semiconscious.

A subclavian venous cannula was inserted and parenteral vitamins, antibiotics, and hydrocortisone ( $2 \mathrm{~g}$. daily) were administered. Calcium gluconate and magnesium sulphate were given to correct biochemical abnormalities (see Table I), and peritoneal dialysis was begun to control body water and electrolytes.

The following day epileptiform fits began, and assisted respiration was instituted after nasotracheal intubation. The limbs were spastic and the left plantar reflex was upgoing.

Her conscious state was variable but she was often deeply unconscious, and on the fifth day a 3.5-litre exchange transfusion of fresh blood was carried out without clinical improvement.

On the sixth day the first of three extracorporeal pig-liver perfusions was carried out. This first perfusion was unsatisfactory because of the inadequate flow rate (see Table II) from a radial artery cannula. There was only marginal improvement in conscious level, though the left plantar reflex became downgoing. A second exchange transfusion of 6 litres was performed the following day but no further clinical improvement occurred.

The second liver perfusion was carried out on the eighth day, and satisfactory flow rates were achieved from a brachial artery cannula. Conscious state was slightly improved.

A tracheostomy was performed after this perfusion because of continued unconsciousness. As the epileptiform seizures were

TABLE 1.-Biochemical and Haematological Data from Patients on Admission

\begin{tabular}{|c|c|c|c|c|c|c|}
\hline \multirow{3}{*}{$\begin{array}{l}\text { Case } \\
\text { No. }\end{array}$} & \multicolumn{6}{|c|}{ Plasma } \\
\hline & Sodium & Potassium & Chloride & $\begin{array}{l}\text { Bicar- } \\
\text { bonate }\end{array}$ & Calcium & $\begin{array}{l}\text { Inorganic } \\
\text { Phosphate }\end{array}$ \\
\hline & \multicolumn{4}{|c|}{$\mathrm{mEq} / \mathrm{l}$. } & \multicolumn{2}{|c|}{$\mathrm{mg} . / 100 \mathrm{ml}$} \\
\hline \multirow[t]{4}{*}{$\begin{array}{l}1 \\
2 \\
3\end{array}$} & $\begin{array}{l}114 \\
134 \\
138\end{array}$ & $\begin{array}{l}4 \cdot 5 \\
4 \cdot 1 \\
4 \cdot 9\end{array}$ & $\begin{array}{l}81 \\
98 \\
98\end{array}$ & $\begin{array}{l}23 \\
23 \\
22\end{array}$ & $\begin{array}{l}7 \cdot 5 \\
8.5 \\
8.5\end{array}$ & $\begin{array}{l}1.2 \\
1.8 \\
4.5\end{array}$ \\
\hline & \multicolumn{6}{|c|}{ Plasma } \\
\hline & \multirow{2}{*}{$\begin{array}{c}\text { Bilirubin } \\
(\mathrm{mg} .1 \\
100 \mathrm{ml} .)\end{array}$} & \multirow{2}{*}{$\begin{array}{c}\text { Alkaline } \\
\text { Phos- } \\
\text { phatase } \\
\text { (K.A. Units/ } \\
100 \text { ml.) }\end{array}$} & $\begin{array}{c}\text { G.O. } \\
\text { Traris- } \\
\text { aminase }\end{array}$ & $\begin{array}{l}\text { G.P. } \\
\text { Trans- } \\
\text { aminase }\end{array}$ & \multirow{2}{*}{$\begin{array}{c}\text { Pro- } \\
\text { thrombin } \\
\%\end{array}$} & \multirow{2}{*}{$\begin{array}{c}\text { Ammonia* } \\
\left(\mathrm{g} . \mathrm{N}_{2} /\right. \\
100 \mathrm{ml} .)\end{array}$} \\
\hline & & & R.F. & Tnits & & \\
\hline $\begin{array}{l}1 \\
2 \\
3\end{array}$ & $\begin{array}{l}17 \cdot 0 \\
29 \cdot 0 \\
28 \cdot 0\end{array}$ & $\begin{array}{l}32 \\
21 \\
30\end{array}$ & $\begin{array}{l}410 \\
650 \\
180\end{array}$ & $\begin{array}{l}110 \\
264 \\
120\end{array}$ & $\begin{array}{l}37 \\
13 \\
23\end{array}$ & $\begin{array}{l}132 \\
265 \\
204\end{array}$ \\
\hline
\end{tabular}

Plasma

\begin{tabular}{|c|c|c|c|c|c|c|}
\hline & \multicolumn{6}{|c|}{ 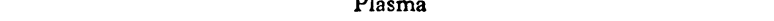 } \\
\hline & \multirow{2}{*}{$\begin{array}{l}\text { Magne- } \\
\text { sium } \\
(\mathrm{mEq} / \mathrm{l} .)\end{array}$} & Urea & Glucose & Albumin & Globulin & \multirow{2}{*}{$\begin{array}{c}\text { Fibrinogen } \\
\text { (mg. } \\
100 \mathrm{ml} .)\end{array}$} \\
\hline & & \multicolumn{2}{|c|}{$\mathrm{mg} / 100 \mathrm{ml}}$. & \multicolumn{2}{|c|}{ g. $/ 100 \mathrm{ml}$. } & \\
\hline $\begin{array}{l}1 \\
2 \\
3\end{array}$ & $\begin{array}{l}1.75 \\
1.4 \\
3.4\end{array}$ & $\begin{array}{r}18 \\
18 \\
130\end{array}$ & $\begin{array}{c}295 \dagger \\
175 \dagger \\
54\end{array}$ & $\begin{array}{l}1 \cdot 5 \\
2 \cdot 3 \\
2 \cdot 4\end{array}$ & $\begin{array}{l}2 \cdot 0 \\
2 \cdot 6 \\
2 \cdot 4\end{array}$ & $\begin{array}{r}97 \\
112 \\
310\end{array}$ \\
\hline & \multicolumn{6}{|c|}{ Blood } \\
\hline & $p \mathrm{H}$ & $\underset{(\mathrm{mm} . \mathrm{Hg})}{\mathrm{PaO}_{3}}$ & $\underset{(\mathrm{mm} . \mathrm{Hg})}{\mathrm{PaCO}_{2}}$ & $\begin{array}{c}\text { Haemo- } \\
\text { globini } \\
\text { (g. } / \\
100 \mathrm{ml} .)\end{array}$ & $\begin{array}{c}\text { Leuco- } \\
\text { cytes } \\
\left(10^{3}\right. \\
\text { cu. } \mathrm{mm} .)\end{array}$ & $\begin{array}{c}\text { Plate- } \\
\text { lets } \\
\left(10^{3} /\right. \\
\text { cu. mm.) }\end{array}$ \\
\hline $\begin{array}{l}1 \\
2 \\
3\end{array}$ & $\begin{array}{l}7 \overline{7.50} \\
7 \cdot 42\end{array}$ & $\begin{array}{l}103 \\
102 \ddagger\end{array}$ & $\begin{array}{l}\overline{31} \\
37\end{array}$ & $\begin{array}{l}11.5 \\
12.8 \\
14.0\end{array}$ & $\begin{array}{r}5 \\
16 \\
28\end{array}$ & $\begin{array}{r}90 \\
150 \\
5\end{array}$ \\
\hline
\end{tabular}

* Hyland blood ammonia method (normal 18-48 $\mu \mathrm{g} . \mathrm{N}_{2} / 100 \mathrm{ml}$.). Glucose infusion at time.

Patient breathing $40 \%$ oxygen.

TABLE II.-Details of Six Heterologous Liver Perfusions in Three Patients

\begin{tabular}{|c|c|c|c|c|c|c|c|c|c|c|c|c|}
\hline \multirow{3}{*}{$\begin{array}{l}\text { Case } \\
\text { No. }\end{array}$} & \multirow{3}{*}{$\begin{array}{l}\text { Perfusion } \\
\text { No. }\end{array}$} & \multirow{3}{*}{$\begin{array}{l}\text { Duration } \\
\text { of } \\
\text { Perfusion } \\
\text { (Hours) }\end{array}$} & \multirow{2}{*}{\multicolumn{2}{|c|}{$\begin{array}{c}\text { Plasma Bilirubin } \\
(\mathrm{mg} . / 100 \mathrm{ml} .)\end{array}$}} & \multirow{2}{*}{\multicolumn{2}{|c|}{$\begin{array}{c}\text { Plasma Ammonia } \\
\left(\mu \mathrm{g} . \mathrm{N}_{2} / 100 \mathrm{ml} .\right)\end{array}$}} & \multirow{3}{*}{$\begin{array}{c}\text { Patient's } \\
\text { Artery } \\
\text { Cannulated }\end{array}$} & \multirow{3}{*}{$\begin{array}{l}\text { Range of } \\
\text { Flow Rate } \\
\text { (ml./min.) }\end{array}$} & \multicolumn{4}{|c|}{ Function of Extracorporeal Liver } \\
\hline & & & & & & & & & \multirow{2}{*}{$\begin{array}{c}\text { Mean } \\
\text { Bile } \\
\text { Volume } \\
\text { (ml.l } \\
\text { Hour) }\end{array}$} & \multirow{2}{*}{$\begin{array}{c}\text { Range of } \\
\text { Bile } \\
\text { Bilirubin } \\
\text { Concentration } \\
\text { (mg./100 ml.) }\end{array}$} & \multirow{2}{*}{$\begin{array}{l}\text { Total* } \\
\text { Bilirubin } \\
\text { Extrac- } \\
\text { tion } \\
\text { (mg.) }\end{array}$} & \multirow{2}{*}{$\begin{array}{c}\text { Mean } \\
\text { Oxygen } \\
\text { Consumption } \\
\text { (ml./100g. } \\
\text { liver/min.) }\end{array}$} \\
\hline & & & $\begin{array}{c}\text { Before } \\
\text { Perfusion }\end{array}$ & $\begin{array}{c}\text { After } \\
\text { Perfusion }\end{array}$ & $\begin{array}{c}\text { Before } \\
\text { Perfusion }\end{array}$ & $\begin{array}{c}\text { After } \\
\text { Perfusion }\end{array}$ & & & & & & \\
\hline $\begin{array}{l}1 \\
2 \\
3\end{array}$ & $\begin{array}{l}1 \\
2 \\
3 \\
1 \\
1 \\
2\end{array}$ & $\begin{array}{l}6 \\
6 \\
6 \\
3 \\
9 \\
8\end{array}$ & \begin{tabular}{r|}
16.9 \\
20.8 \\
$18 \cdot 0$ \\
25.5 \\
21.0 \\
5.5
\end{tabular} & $\begin{array}{r}13 \cdot 5 \\
14 \cdot 0 \\
14.0 \\
15 \cdot 0 \\
6.5 \\
2.0\end{array}$ & $\begin{array}{r}132 \\
135 \\
92 \\
265 \\
256 \\
52\end{array}$ & $\begin{array}{r}132 \\
140 \\
103 \\
210 \\
83 \\
70\end{array}$ & $\begin{array}{c}\text { Radial } \\
\text { Brachial } \\
\text { ", } \\
\text { ", } \\
\text { ", }\end{array}$ & $\begin{array}{l}200-300 \\
600-850 \\
600-680 \\
200-400 \\
500-650 \\
600-650\end{array}$ & $\begin{array}{r}1.9 \\
8.4 \\
10.6 \\
9.5 \\
19.9 \\
21.8\end{array}$ & $\begin{array}{l}57-164 \\
62-144 \\
72-116 \\
250-550 \\
75-235 \\
75-90\end{array}$ & $\begin{array}{r}24 \\
160 \\
235 \\
295 \\
214 \\
143\end{array}$ & $\begin{array}{l}= \\
\bar{Z} \\
3 \cdot 0 \\
3 \cdot 3 \\
2 \cdot 8\end{array}$ \\
\hline
\end{tabular}


uncontrolled with phenobarbitone or phenytoin sodium and only marginally improved by correction of hypocalcaemia, curarization became necessary.

As there had been no clinical improvement the third liver perfusion was performed on the tenth day (see Table II). There was slight improvement in conscious level during this perfusion.

Melaena began some hours after completion of the third perfusion and continued in minor quantities until the patient died five days later. Peritoneal dialysis was continued throughout, but the blood urea rose gradually to $92 \mathrm{mg} . / 100 \mathrm{ml}$. Serum bilirubin rose to 31 $\mathrm{mg} . / 100 \mathrm{ml}$. The patient gradually developed pulmonary congestion and pneumonia, but removal of fluid by hypertonic dialysis resulted in hypotension. A blood culture on the day before death grew Pseudomonas pyocyanea. The patient died on the thirteenth day after admission, there having been no deterioration in her conscious level from the time of the third perfusion until shortly before death.

Necropsy Findings. - The liver was large (3,700 g.) and contained multiple necrotic areas. Microscopically, the lobules were preserved but there was fibrosis and a heavy cellular infiltrate in the portal tracts. Bile ducts were normal. There was marked centrilobular cell necrosis and fatty change. Both lungs contained multiple nodules of anaplastic tumour tissue consistent with origin from malignant melanoma. The brain was macroscopically normal. There was patchy ulceration of the gastric and proximal duodenal mucosa.

Comment.-The course of this patient illustrates the multiplicity of clinical problems that may be encountered in liver failure. Death was probably due to cardiorespiratory failure as there had been no deterioration in the level of consciousness over the terminal five days. The metastatic tumour in the lungs may have contributed to the terminal pulmonary insufficiency.

\section{Case 2}

A 50-year-old woman was admitted to hospital unconscious in November 1966. She had had dyspepsia and two haematemeses during the previous year from a gastric ulcer, and menorrhagia for two years treated by uterine currettage three weeks previously. She had malaise and vomiting after meals for five weeks and deepening jaundice for two weeks; five days before admission she became drowsy and developed a flapping tremor. When first examined she had been comatose for 18 hours. There was no history of alcoholism or exposure to chemicals or drugs, and her only contact with infectious hepatitis was six months peviously.

She was deeply jaundiced and unconscious, responding only to painful stimuli. There was no fetor or flapping tremor. The blood pressure was $140 / 80 \mathrm{~mm}$. $\mathrm{Hg}$, pulse $80 / \mathrm{min}$., temperature $36.8^{\circ} \mathrm{C}$., and respirations $16 / \mathrm{min}$., deep and stertorous.

The liver was impalpable, liver dullness was absent, and free fluid was not detected. The chest was normal. All limbs were spastic with hyperactive deep reflexes; plantar reflexes were upgoing.

Haematological and biochemical investigations are summarized in Table I. A lumbar puncture was normal. A blood culture subsequently grew Streptococcus faecalis and paracolon bacilli.

Treatment was begun with nasotracheal intubation and oxygen administration. A nasogastric tube, a subclavian venous cannula, and a brachiocephalic arteriovenous shunt were inserted. Infusions of $20 \%$ fructose and hydrocortisone ( $2 \mathrm{~g}$. daily) were given. Neomycin was given orally.

Over the next 12 hours she became more unconscious and her respirations became deeper, laboured, and rapid (36/min.); the venous plasma bicarbonate fell to $13 \mathrm{mEq} / 1$. and the arterial $\mathrm{pH}$ to 7.30. It was felt that survival was unlikely, and heterologous liver perfusion was begun 20 hours after admission. Before perfusion the blood pressure fell to $60 \mathrm{~mm}$. $\mathrm{Hg}$, but was restored to $120 \mathrm{~mm}$. $\mathrm{Hg}$ after $44 \mathrm{mEq}$ of sodium bicarbonate and $500 \mathrm{ml}$. of blood were given intravenously.

During perfusion the flow rate was never satisfactory, and acidosis ( $p \mathrm{H} 7.30$ to 7.34) persisted despite a further $176 \mathrm{mEq}$ of sodium bicarbonate over two hours. The blood pressure was maintained between 100 and $110 \mathrm{~mm} . \mathrm{Hg}$, but the respiration rate increased to 40 and copious pink frothy fluid was aspirated from the nasotracheal tube. Perfusion was discontinued after three hours because of the patsent's poor general condition.
After perfusion, acidosis persisted and hypotension developed, though this was temporarily corrected with infusions of $5 \%$ albumin. The patient died of a cardiac arrest five hours after perfusion and 28 hours after admission.

Necropsy Findings.-The patient's liver was small, soft, and bilestained, weighing $890 \mathrm{~g}$. Microscopically there was almost total necrosis of parenchymal tissue with chronic inflammatory infiltration both of the portal tracts and throughout the degenerative parenchymal tissue. The stomach was grossly dilated with food, and fluid gastric contents were present throughout the minor bronchi of the left lung.

Comment.-The presence of a persistent and uncorrectable metabolic acidosis and a labile circulation makes it unlikely that any treatment would have availed. Respiratory problems arising after aspiration of gastric content early in the course of hepatic failure were also detrimental to the outcome. In spite of the poor perfusion of the pig liver, significant bilirubin excretion was obtained (Table II).

\section{Case 3}

A 22-year-old woman was admitted to hospital in October 1966 in her 37th week of pregnancy. For nine days she had experienced lassitude, anorexia, nausea, and vomiting, and for two days had a mild fever. On admission she was mildly jaundiced. Uterine contractions began soon afterwards and the membranes ruptured. Labour continued for 66 hours until a stillborn child was delivered. During this period the patient had vomited and become drowsy, incoherent, and progressively more jaundiced. Hypotension (80$90 \mathrm{~mm}$. Hg systolic) and oliguria developed 24 hours before delivery and continued for $\mathbf{4 8}$ hours. Further deterioration occurred, and she lapsed into coma 48 hours after delivery.

She was referred to us after being in coma for 18 hours. She was unconscious, responding sluggishly to painful stimuli, was deeply jaundiced, and had fetor hepaticus. Her temperature was $38.5^{\circ}$ C., pulse $155 / \mathrm{min}$., blood pressure $120 / 80 \mathrm{~mm}$. $\mathrm{Hg}$, and respirations $22 / \mathrm{min}$. Breathing was laboured and noisy, and there were bilateral coarse crepitations. The abdomen was distended, and the liver and spleen were not palpable. The uterine fundus was palpable, and a profuse mucopurulent vaginal discharge was present. Moderate calf and ankle oedema and a raised erythematous rash on the thighs and arms were present. All limbs were spastic, with hyperactive deep reflexes and upgoing plantar responses.

Investigations performed are summarized in Table I. The bloodclotting time was accelerated owing to depression of antithrombin factors. An $x$-ray film of the chest and lumbar puncture showed nothing abnormal. Blood culture and a marrow culture grew Escherichia coli; culture of the vaginal discharge grew $E$. coli and Str. faecalis.

Treatment included nasotracheal intubation, subclavian venous cannulation, institution of peritoneal dialysis, and parenteral antibiotics and vitamins. Hydrocortisone ( 2 g. daily) was given parenterally.

No improvement occurred over the next 12 hours and extracorporeal pig-liver perfusion was begun 28 hours after admission (see Table II and Fig. 2). Definite improvement in conscious state occurred over this nine-hour perfusion, with the onset of restlessness and semipurposeful movements.

For 15 hours after perfusion there was slight improvement in conscious state, the plantar responses became downgoing, and the serum bilirubin rose to $9 \mathrm{mg} . / 100 \mathrm{ml}$. An exchange transfusion was performed with 5 litres of fresh heparinized blood with a fall in serum bilirubin from 9 to $4 \mathrm{mg} . / 100 \mathrm{ml}$. (Fig. 2). Melaena began and continued intermittently over the next three days. The conscious state was marginally improved next day and a further extracorporeal pig-liver perfusion was carried out over eight hours (see Table II). During this perfusion rapid improvement occurred, the patient obeying commands and making purposeful movements with her limbs.

Three hours after this perfusion she began to speak, and over the next week regained full consciousness, though dysarthria and ataxia continued for a further three weeks. Serum bilirubin rose to $6 \mathrm{mg} . / 100 \mathrm{ml}$., but then slowly fell to reach $1.1 \mathrm{mg} . / 100 \mathrm{ml}$. three weeks after admission.

Peritoneal dialysis was continued uninterruptedly for 15 days until renal function improved, with maintenance of blood urea at 
normal levels. Protein was slowly introduced into the diet, while the steroid dosage was reduced and discontinued six weeks after admission.

Five weeks after admission the patient again became febrile and the white cell count rose to $16,000 /$ cu.mm., with 3,200 abnormal mononuclear cells. The spleen became palpable. Investigations revealed a negative Paul-Bunnell test after ox-cell and guinea-pig absorption, and a cytomegalic virus was cultured from the blood. The pyrexia subsided and the patient was discharged seven weeks after admission to hospital. At the time of discharge she was fully ambulant and takung a full diet; she was, however, euphoric and her behaviour slightly immature and uninhibited.
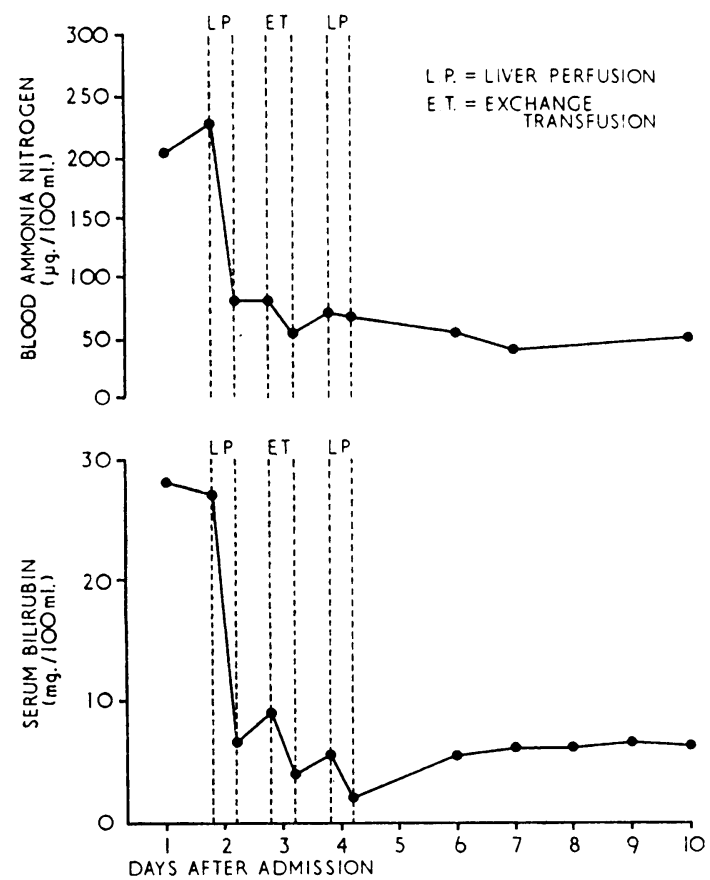

FIg. 2.-Case 3. Serial concentrations of blood ammonia nitrogen and serum bilirubin over the first 10 days, showing the dramatic response to treatment.

At the time of discharge the serum bilirubin was $0.6 \mathrm{mg} . / 100 \mathrm{ml}$, alkaline phosphatase 19 units, S.G.O.T. 22 R.F. units, S.G.P.T. 49 R.F. units, prothrombin $50 \%$, serum albumin 3.5 g. $/ 100 \mathrm{ml}$., serum electrolytes normal, blood urea $35 \mathrm{mg} . / 100 \mathrm{ml}$., creatinine clearance $73 \mathrm{ml} . / \mathrm{min}$., and blood ammonia $40 \mu \mathrm{g} . / 100 \mathrm{ml}$.

Comment.-Acute liver failure in this patient was complicated by septicaemia and renal failure. She was successfully treated by intensive medical care supplemented by peritoneal dialysis, extracorporeal pig-liver perfusion, and exchange transfusion. A definite diagnosis was not made, but infective hepatitis or acute fatty infiltration of pregnancy (Sheehan, 1940) was thought to be the most likely.

\section{Discussion}

The course of these three patients with hepatic failure illustrates the great variety of clinical problems which such patients present. Special techniques, such as heterologous liver perfusion, are therefore unlikely to be of value without careful attention to these complications. The major problems encountered in these patients are described.

Airway Obstruction and Hypoxia.-Two patients were hypoxic when first examined and in both the cause was simple airway obstruction. As illustrated by Case 2, aspiration of gastric contents must be prevented. Just how important hypoxia can be in the genesis of coma in patients with chronic liver disease is illustrated by one of our patients with cirrhosis of the liver who developed pneumonia and became comatose; within 12 hours of beginning treatment with oxygen and antibiotics this patient had regained consciousness.
Disturbances of Acid-base Balance, Body Water, and Electrolyte Concentrations.-Hyperventilation leading to respiratory alkalosis often develops in patients with hepatic failure (Vanamee et al., 1956). On the other hand, respiratory obstruction, shock, and hepatic impairment may lead to respiratory or metabolic acidosis so that determination of arterial $p \mathrm{H}$ is necessary, as mixed acid-base disturbances are often present. Only one of these patients presented a therapeutic problem in acid-base balance-an uncorrectable metabolic acidosis, which is reported as an uncommon finding in hepatic failure (Schwartz et al., 1953). This acidosis may have been the consequence of organic acid accumulation due either to hepatic disease or to a generalized reduction in tissue perfusion. A hazard for the patient with chronic liver disease is that of fluid and electrolyte depletion from diuretic therapy as occurred in one of the patients with cirrhosis of the liver referred to us in coma. This patient rapidly regained consciousness after correction of the fluid and electrolyte deficit. Hypocalcaemia was present in all patients, and in Case 1 its correction was associated with an abrupt decrease in the frequency of epileptiform fits. Hypomagnesaemia, which is not uncommonly found in patients with hepatic cirrhosis (Stutzman and Amatuzio, 1953 ; Flink et al., 1955), was present in one patient.

Renal Failure.-Renal failure, which commonly accompanies acute hepatic failure, occurred in two patients. In the patient who recovered, improvement in renal function was coincident with improvement in hepatic function. Peritoneal dialysis was employed in both patients with renal failure; it successfully controlled azotaemia and maintained water and electrolyte homoeostasis. Its use in hepatic coma has been reported by Jones et al. (1959), Maxwell et al. (1959), and Nienhuis et al. (1963). We believe that the indications for peritoneal dialysis in such patients are twofold: (1) to treat established renal failure, and (2) to maintain control of water exchange and electrolyte concentrations. In such patients, as in those with acute renal failure, it is our practice to continue peritoneal dialysis in an uninterrupted fashion to prevent rather than treat the consequences of azotaemia and derangements of fluid and electrolyte metabolism.

Though peritoneal dialysis carries a risk of peritoneal infection, this risk does not appear to be any greater in patients with hepatic disease. The procedure used in these patients involves microfiltration of the dialysate inflow and ultraviolet sterilization of the dialysate outflow (Gurr, 1967) in addition to isolation of the patient. Peritoneal dialysis conducted in this manner has reduced the incidence of infection to negligible levels in patients undergoing continuous dialysis for two or more weeks.

Septicaemia.-Septicaemia due to Gram-negative organisms is a recognized complication of chronic liver disease (Whipple and Harris, 1950 ; Martin et al., 1956). All three patients developed a septicaemia. In two of them this was present at the time of admission and in the third only in blood taken for culture the day before death. We believe that repeated blood cultures should be performed on patients in acute liver failure irrespective of a clinical indication of infection.

Gastrointestinal Bleeding.-This is the commonest manifestation of the coagulation defect in hepatic failure and occurred in two of the three patients. All three exhibited thrombocytopenia and a prolonged prothrombin time. It is of interest that the patient who survived had an accelerated clotting-time despite a prolongation of the prothrombin time and a thrombocytopenia ; this paradoxical state occurred as the result of a profound depression of antithrombin factors. The coagulation abnormalities of severe hepatic failure are reported to be reversible with fresh human blood (Schenk et al., 1957 ; Finkbiner et al., 1959). We have therefore employed fresh heparinized blood for perfusion, for exchange transfusions, and for standard transfusions as a prophylactic measure against bleeding. 
Hypoglycaemia.-This complication occurred in one patient, but its correction had no effect on her conscious state.

Status Epilepticus.-This occurred in one patient, who ultimately required curarization. Correction of hypocalcaemia decreased the frequency of fitting.

\section{Experience with Extracorporeal Pig-liver Perfusion}

There was a definite lightening of consciousness and increased responsiveness to stimulation during five of the six perfusions. The most dramatic response occurred during the second perfusion in Case 3. At the onset of perfusion this patient responded only to painful stimuli, but after four hours she obeyed verbal commands and at the completion of the perfusion was able to speak. The electroencephalogram in this case showed a steady progression from delta rhythm to normal over the three-day treatment period.

The ability of the extracorporeal liver to extract bilirubin and ammonia from the plasma, to secrete bile, and to utilize oxygen is well illustrated by the results presented in Table II and Fig. 2. It seems likely that considerable amounts of bilirubin were retained in the pig liver and therefore not included in the estimated total bilirubin output in the bile and ascitic fluid (Table II).

The blood flow required for optimal function in the pig liver is at least $0.5 \mathrm{ml} . / \mathrm{g}$. liver/minute (Tait and Eiseman, 1966). The flow rate in two of the six perfusions was inadequate-in one (Case 1) because of the use of a radial artery shunt, in the other (Case 2) probably because of the reduced cardiac output of a very ill patient. The relatively large shunt necessary for this procedure to be effective may militate against its use in patients with a poor circulation, and other methods may have to be sought to perfuse a heterologous liver adequately in such patients. However, if the shunt can be sustained it seems evident from our limited experience that the acidosis and hypotension of heterologous dog-pig-liver perfusion (Drapanas et al., 1966) does not occur.

The duration for which perfusion can be continued is not known, but the two perfusions in Case 3, of eight and nine hours respectively, had no apparent ill effect on this young patient's cardiovascular system. In addition, in all perfusions bile production and bilirubin excretion continued until perfusion was stopped.

Our experience of heterologous liver perfusion coupled with that of others shows that the procedure is technically feasible and that the heterologous organ functions during perfusion. Its place in the treatment of acute liver failure remains to be defined. The gratifying result in Case 3 , where a young woman suffering from a condition previously shown to be almost invariably fatal has made a full recovery, is of itself encouragement enough to justify continued trial of the method in such patients. Further studies will be required to show if an immunological hazard exists, though there has been no evidence of this in our surviving patient.

It may not be too speculative to consider that heterologous perfusion for acute liver failure is at a similar stage now to that of dialysis in relation to renal failure 15 years ago. At that time this procedure was applied to the seriously ill patient with terminal uraemia, and the overall results were poor despite an occasionally dramatic success. Now dialysis is widely employed to maintain normality rather than to correct established and dangerous abnormality. If it proves possible to develop a similar early assessment of liver failure a wider application of aggressive techniques such as heterologous perfusion can be foreseen.

\section{Summary}

This is a report of three patients comatose from liver failure and referred for treatment by extracorporeal pig-liver perfusion.
Two further patients with chronic liver disease were also referred for treatment, but correction of an obvious precipitating factor in each produced a rapid recovery of consciousness without recourse to perfusion.

Three patients who had no history of previous liver disease were treated with a total of six perfusions and one survived.

Attention is drawn to the wide variety of complications that beset patients with liver failure. Treatment of these complications is essential before special techniques such as heterologous liver perfusion are employed.

ADDENDUM.-Since preparation of this paper, immunological studies on the surviving patient (Case 3 ) have been carried out by Dr. Philip Ironside, Department of Pathology, Monash University.

Porcine serum protein was detected in decreasing amounts in the patient's serum for 20 days after the last perfusion.

Although precipitating antibodies were not found at any stage up to 39 days after the first perfusion, the patient's serum agglutinated tanned red cells coated with porcine serum protein. A titre of 1 in 8 was obtained on the 16th day after perfusion, rising to 1 in 256 on the 37 th day, when the last blood sample was taken.

It is a pleasure to thank Dr. M. Davis, Dr. R. Lucas, Dr. I. Lyall, Dr. P. Parsons, and Dr. M. Whiteside for referring patients, and Dr. G. Jones for undertaking extensive haematological investigations.

The work is supported by grants-in-aid from the National Health and Medical Research Council and the Patrick Brennan Trust.

\section{REFERENCES}

Berger, R L., Liversage, R. M., Chalmers, T. C., Graham, J. H., McGoldrick, D. M., and Stohlman, F. (1966). New Engl. F. Med., 274, 497.

Burnell, J. M., et al. (1965). Amer. F. Med., 38, 832.

Cook, G. C., and Sherlock, S. (1965). Lancet, 1, 175.

Drapanas, T., Zemel, R., and Vang, J. O. (1966). Ann. Surg., 164, 522.

Eiseman, B. (1966). Ann. roy. Coll. Surg. Engl., 38, 329.

Eiseman, B. (1966). Ann. roy. Coll. Surg. Engl., 38, 329.

- Van Wyk, J., and Griffen, W. O. (1966). Surg., Gynec. Obstet., 123,522 .

Finkbiner, R. B., McGovern, J. J., Goldstein, R., and Bunker, J. P. (1959). Amer. F. Med., 26, 199.

Flink, E. B., Konig, T. J., and Brown, J. L. (1955). F. Lab. clin. Med., $46,814$.

Foulk, W. T., Butt, H. R., Stauffer, M. H., Baggenstoss, A. H., and Gross, J. B. (1955). Gastroenterology, 29, 171.

Gurr, F. W. (1967). Unpublished data.

Jones, R. C., Strader, L. D., and Berry, W. C. (1959). U.S. armea Forces med. F., 10, 977.

Katz, R., Velasco, M., Klinger, J., and Alessandri, H. (1962). Gastroenterology, 42, 258 .

Lee, C., and Tink, A. (1958). Med. F. Aust., 1, 40.

McDonald, R., and de la Harpe, P. L. (1963). F. Pediat., 63, 916.

Martin, W. J., Spittel, J. A., Morlock, C. G., and Baggenstoss, A. H. (1956). Arch. intern. Med., 98, 8.

Maxwell, M. H., Rockney, R. E., Kleeman, C. R., and Twiss, M. R. (1959). Amer med. Ass., 170, 917.

Nayman, J. (1964). Trans. Amer. Soc. artif. intern. Organs, 10, 127.

Nienhuis, L. I., Mulmed, E. I., and Kelley, J. W. (1963). Amer. 7. Surg., 106, 980.

Schenk, W. G., Fopeano, J., Cosgriff, J. H., and Gray, J. G. (1957). Surgery, 42, 822 .

Schwartz, R., Phillips, G. B., Gabuzda, G. J., and Davidson, C. S. (1953). f. Lab. clin. Med., 42, 499.

Sen, P. K., Bhalerao, R. A., Parulkar, G. P., Samsi, A. B., Shah, B. K.. and Kinare, S. G. (1966). Surgery, 59, 774.

Sheehan, H. L. (1940). F. Obstet. Gynaec. Brit. Emp., 47, 49.

Sherlock, S. (1963). Diseases of the Liver and Biliary System, 3rd ed Oxford.

Starzl, T. E., Marchioro, T. L., Faris, T. D., McCardle, R. J., and Iwaski, Y. (1966). Amer. F. Surg., 112, 391.

Stutzman, F. L., and Amatuzio, D. S. (1953). F. Lab. clin. Med., 41, 215.

Tait, I. B., and Eiseman, B. (1966). Arch. Surg., 93, 131.

Trey, C., Burns, D. G., and Saunders, S. J. (1966). New Engl. f. Med.,

274, 473.
Vanamee, P., Poppell, J. W., Glicksman, A. S., Randall, H. T., and Roberts, K. E. (1956). Arch. intern. Med., 97, 762.

Whipple, R. L., and Harris, J. F. (1950). Ann. intern. Med., 33, 462. 